Ann. Biol. anim. Bioch. Biophys, I976, 16 (2), 205-2II.

\title{
CYCLIC AMP AND THE MECHANISM OF ACTION OF GONADOTROPIN RELEASING HORMONE (LH-RH)
}

\author{
M. JUTISZ, Annette BÉRAULT and Madeleine THEOLEYRE \\ Laboratoire des Hormones polypeptidiques, C.N.R.S., \\ 91190 Gif sur Yvette
}

\section{SUMMARY}

Most experimental results favour the hypothesis that cyclic AMP is an intermediate in the releasing action of gonadotropin releasing hormone (LH-RH). This would imply first a reversible binding of LH-RH to the specific plasma membrane receptors with the subsequent activation of adenylate cyclase, which would then catalyse the conversion of ATP to cAMP. How cAMP then promotes hormone release is not known. As a working hypothesis, it is suggested that cAMP participates in phosphorylation processes which represent an essential step in the release mechanism.

Our discussion will be limited to two main problems : first the binding of LH-RH to the receptor sites of the pituitary gland, and second, the probability of cyclic AMP being an intermediate of the releasing action of LH-RH.

\section{I. - STUDIES ON THE BINDING OF LH-RH}

\section{TO THE RECEPTOR SITES OF THE PITUITARY GLAND}

Many experimental results, which will be discussed in the second part of this paper, favour the hypothesis that cyclic AMP is an intermediate in the action of $\mathrm{LH}$ $\mathrm{RH}$. This would imply first a reversible binding of the hormone to specific plasma membrane receptors. In order to study the interaction of a hormone with its receptor sites, at least three conditions are necessary : (I) the hormone should be homogeneous and it should be labelled with a radioactive isotope in such a manner that its initial conformation is not disturbed and its binding sites are not blocked, (2) the binding 


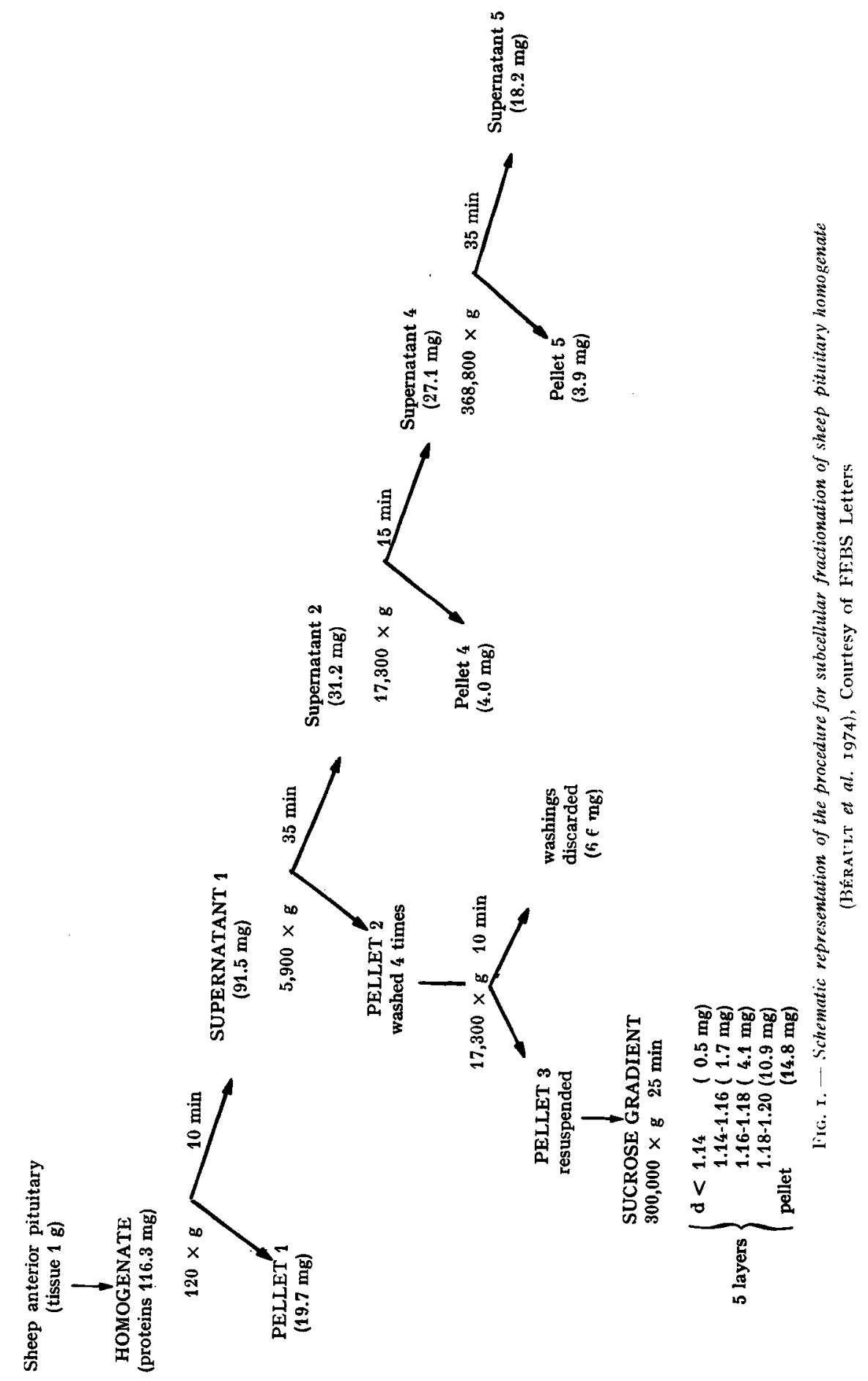


to the receptor sites should be specific and reversible, (3) the binding should be correlated with a physiological response. These conditions have so far been met only partially for LH-RH.

Several reports have already described a specific interaction between another hypothalamic hormone, TRH, and pituitary plasma membranes (see references in JUTISZ and KRAICER, I975). Less work has been done on the binding of LH-RH.

Using normal rat anterior pituitary cells in culture, GRANT et al. (I973) have shown that there exists, as for TRH, two distinct binding sites for tritiated LH-RH, one of which has the parameters of the physiological LH-RH receptor. Data on the binding of ${ }^{125} \mathrm{I}$ labelled LH-RH were also reported by SpoNA (I973 $a, b$, 1974).

In our laboratory, plasma membranes from ovine anterior pituitary glands were prepared by a simple and rapid method schematized in figure I (BÉRAULT et al., 1974). Plasma membranes, characterized by electron microscope examination and by marker enzyme assay, are present in the upper layer of the sucrose gradient of a density less than I.I4.

The binding studies were performed at ${ }^{\circ} \mathrm{C}$ in a Tris- $\mathrm{MgCl}_{2}$-sucrose, $\mathrm{pH} 7.4$ buffer. In a standard procedure, $50 \mu \mathrm{g}$ of membranes were incubated with tritiated LH-RH in a whole volume of $220 \mu 1$ (BÉRAuLT et al., I973).

Tritiated LH-RH was prepared from synthetic LH-RH (kindly supplied by Dr. Studer, Hoffmann-La Roche, Basle) by Drs MARChe and Morgat (Laboratory of Dr. P. Fromageot, C.E.A., Saclay) and by Drs Roncari and Gilitessen (Hoffmann-La Roche, Basle). LH-RH was tritiated in the tyrosine residue according to MARCHE et al. (1972) ; its specific radioactivity was $35-55 \mathrm{Ci} / \mathrm{mMole}$.

The kinetic studies at $0^{\circ} \mathrm{C}$ showed that the maximum binding occurred after $20 \mathrm{~min}$ of incubation. The addition of a $\mathrm{I}$ ooo-fold excess of cold hormone to the reaction mixture resulted in the displacement of $75 \mathrm{p}$. roo of the bound ${ }^{3} \mathrm{H}-\mathrm{L} / \mathrm{H}-\mathrm{RH}$.

Incubation of plasma membranes with constant doses of ${ }^{3} \mathrm{H}-\mathrm{L} / \mathrm{H}-\mathrm{RH}$ and graded doses of LH-RH showed that a Ioo-fold excess of LH-RH would completely inhibit the binding of tritiated hormone.

A dose effect study at $0^{\circ} \mathrm{C}$ suggests two types of binding sites for ${ }^{3} \mathrm{H}-\mathrm{L}-\mathrm{H}-\mathrm{RH}$ (as in the case of experiments reported by GRANT et al., 1973), one type with a high affinity and low capacity and the other with a low affinity and much higher capacity. The latter type of sites may represent non specific binding sites of LH-RH due to the fact that they are apparently non saturable (BÉRAUL'r et al., I973).

From the data of the Scatchard plot we calculated the association constant of the high affinity sites which is :

$$
\mathrm{K}_{\mathrm{ass}}=4.7 \times 10^{10} \mathrm{M}^{-1}
$$

and the number of sites is :

$$
n=3 \times 10^{-12} \mathrm{moles} / \mathrm{mg}
$$

These data are very close to those published in the literature for the binding of other polypeptide hormones.

The question arises as to whether the receptors for $\mathrm{LH}-\mathrm{RH}$ on the plasma membranes of the pars distalis cells are functionnally related to the adenylate cyclase system and thus the release process. This will now be discussed. 


\section{II. - IS CYCLIC AMP AN INTERMEDIATE}

\section{IN THE RELEASING ACTION OF LH-RH}

In order to establish that cAMP mediates the action of releasing hormones, the following criteria must be fulfilled (ROBISON et al., I97I) : (I) the releasing hormone should stimulate adenylate cyclase activity in tissue homogenate, (2) the releasing hormone should increase cAMP levels in intact cells or/and tissue, and this increase should precede the release of hormone, (3) exogenous cAMP or its derivatives should stimulate hormone release from the anterior pituitary gland, (4) phosphodiesterase inhibitors (theophylline) should potentiate the action of the releasing hormone to increase hormone release.

The first condition, stimulation of adenylate cyclase activity in a homogenate of pituitary gland has, to our knowledge, never been met for synthetic LH-RH. To explain these negative results it may be argued that gonadotrophs represent only a relatively small proportion of the pituitary cell population $(5-6$ p. I0o), so that an increase in the LH-RH induced adenylate cyclase activity over that of the basal activity would be difficult to demonstrate.

The second condition, enhancement of CAMP levels in incubated tissue or dispersed cells under the action of LH-RH, has been reported by several laboratories (BORGEAT et al., I972, I974; KANEKo et al., I972, I973; Makino, I973).

As to the third criterion, many in vitro studies have demonstrated that CAMP or dibutyryl cAMP will increase the release of LH (RATNER, I970; JUTISz et al., I970 ; Makino, I973 ; Groom and Boyns, I973) and that of FSH (JuTISz and de la LLOSA, I969, I970).

It was also shown that sodium fluoride, which is known to activate adenylate cyclase by a direct action, will promote the release of LH from pituitary halves in vitro (JuTISz et al., I972).

The fourth condition, potentiation of the action of LH-RH by phosphodiesterase inhibitors has been repeatedly demonstrated in vitro. Theophylline will not by itself stimulate the release of FSH (JUTISZ and de la LLOSA, 1969) and LH (JUTISz et al., 1970). However, theophylline does potentiate the action of a purified preparation of I,H/FSH-RF, extracted from ovine hypothalami, to release FSH (JUTISZ and de la LL,OSA, I969) and LH (JuTisz et al, r970).

Nevertheless, there are also some arguments against the participation of cAMP. As mentioned above, theophylline alone was unable to release either $\mathrm{LH}$ or FSH from rat pituitary glands in vitro, although it increased the cAMP level in the pituitary tissue (ZOR et al., I972). On the other hand, we did not succeed in activating adenylate cyclase in the plasma membranes from ovine adenohypophysis although this enzyme could be activated with $\mathrm{NaF}$ (unpublished results).

NAOR et al. (I975) reported other arguments against the participation of cAMP. Administration of $\mathrm{LH}-\mathrm{RH}$ in the rat in vivo increased the serum level of LH within I5 min without increasing pituitary cAMP. Under similar conditions, prostaglandin $\mathrm{E}_{\mathbf{2}}\left(\mathrm{PGE}_{2}\right)$ both stimulated cAMP production and raised the serum $\mathrm{LH}$ level. These 
authors also showed that in vitro incubation of hemipituitaries for 4 hr with LH-RH, $\mathrm{PGE}_{2}$, choleragen (cholera toxin), theophylline and IBMX (3-isobutyl-I-methylxanthine) raised pituitary cAMP accumulation but only $\mathrm{L}_{1} \mathrm{H}-\mathrm{RH}$ stimulated $\mathrm{LH}$ release into the medium.

It may be argued that the pituitary gland represents a mixed cell population with only a relatively small proportion of gonadotrophs, and that most of the drugs which raised pituitary cAMP accumulation affected cell types other than the gonadotrophs. On the other hand, it was shown that the stimulation of pituitary LH release in vivo by $\mathrm{PGE}_{2}$ is probably due to the stimulation of hypothalamic secretion of LH-RH (CHOBSIENG et al., I975).

\section{III. - HYPOTHETICAL MODEL}

\section{OF THE MECHANISM OF ACTION OF LH-RH}

In addition to CAMP, another element, $\mathrm{Ca}^{++}$, participates in the mechanism of action of LH-RH. This particular point has been developed in a paper that we recently published (JuTISz et al., I975) and we shall not discuss it here.

Integration of all information so far available, suggested a hypothetical model of the mechanism of action of LH-RH (fig. 2), recently proposed (JUTISZ and KRAICER, 1975). This scheme is partially based on the Sutherland model (SuTHERLAND

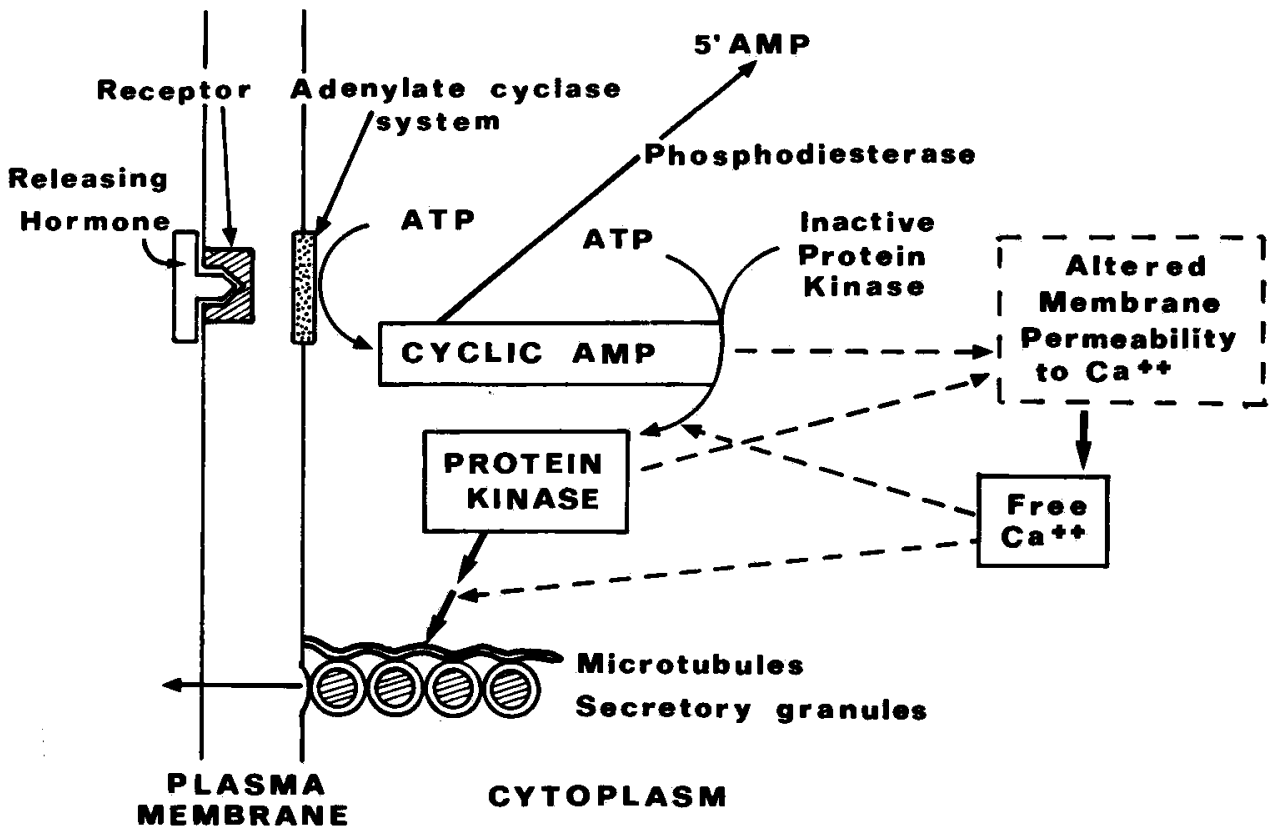

FIG. 2. - Hypothetical model of the cellular mechanism of action of a hypothalamic releasing hormone

(Jutisz and Kraicer, I975), Courtesy of Verlag Chemie. 
et al., 1965). The releasing hormones will first bind to a specific membrane receptor site of a gonadotropic cell and will initiate activation of the adenylate cyclase system through a mechanism which is still unknown. Cyclic AMP which is formed will act on the release of $\mathrm{Ca}^{++}$from the cell membrane proteins, $\mathrm{Ca}^{++}$being necessary for promoting many intracellular enzymatic processes. Cyclic AMP also activates a protein kinase which acts on a phosphorylase kinase participating in the phosphorylation processes. Phosphorylation is probably an important event in the releasing mechanism, but the remainder of this mechanism has still to be discovered.

\section{IV. - CONCLUDING REMARKS}

It is rather difficult to draw any precise conclusion from these somewhat puzzling and sometimes conflicting results concerning the possible role of cAMP as a mediator of hypothalamic hormone. Nevertheless, in the light of reported results, we still believe that cAMP is really involved in the mechanisms of action of gonadotropin releasing hormone. NAKANE (I970) reported the identification in the rat pituitary of three types of gonadotropic cells, one type containing both $\mathrm{LH}$ and FSH and the other two containing only LH or FSH. It is possible that the mechanisms by which gonadotropins are released from various types of pituitary cells are different. Cyclic AMP may be involved in one of these mechanisms but not in the others.

We have tried to make a critical review of the central role that cAMP may play in the mechanism of action of LH-RH. We have made no attempt to conceal the many problems which have not yet been solved.

Symposium Gn-RH, Tours, 25 mars 1975.

\section{RÉSUMÉ}

\section{AMP CYCLIQUE ET MÉCANISME D'ACTION DE L'HORMONE DE LIBÉRATION DES GONADOTROPINES (LH-RH)}

La plupart des résultats expérimentaux sont en faveur de l'hypothèse səlon laquelle l'AMP cyclique serait un intermédiaire dans l'action du LH-RH sur la libération de LH par l'hypophyse. Ceci impliquerait d'abord une liaison réversible du LH-RH aux récepteurs des membranes plasmiques avec activation de l'adényl cyclase qui catalyserait la conversion d'ATP en AMPc. Le processus selon lequel l'AMPc entraîne la libération de la LH n'est pas connu. L'AMPc participe probablement aux réactions de phosphorylation impliquéss dans le mécanisme de libération des gonadotropines.

\section{REFERENCES}

BÉRAult A., ThÉoleyre M., Jutisz M., I973. Interaction entre l'hormone hypothalamique LH-RH et ses récepteurs. Étude des membranes plasmiques hypophysaires. In Les mécanismes d'action hor. monale, and Colloquium of Royaumont (France), October 25-27 (Abstracts). 
Bérault A., ThÉoleyre M., Jutisz M., I974. A simplified method for the preparation of plasma membranes from ovine anterior pituitary glands. FEBS Letters, 39, 267-270.

Bokgeat P., Chavancy G., Dupont A., Labrie F., Arimura A., Schally A. V., I972. Stimulation of Adenosine $3^{\prime}: 5^{\prime}$-cyclic monophosphate accumulation in anterior pituitary gland in vitro by synthetic luteinizing hormone-releasing hormone. Proc. Nat. Acad. Sci. U.S. A., 69, 2677-2681.

Borgeat P., labrie F., Côté J., Ruel F., Schally A. V., Coy D. H., Coy E. J., Yanaihara N., I974. Parallel stimulation of cyclic AMP accumulation and LH and FSH release by analogs of LH-RH in vitro. Molec. Cell. Endocrin., 1, 7-21.

Chobsieng P., Naor Z., Koch Y., ZoR U., Lindner H. R., I975. Stimulatory effect of Prostaglandin $\mathrm{E}_{2}$ on $\mathrm{LH}$ release in the Rat : Evidence for hypothalamic site of action. Neuroendocrinology 17, $12-17$.

Grant G., Vale W., Rivier J., I973. Pituitary binding sites for $\left({ }^{3} \mathrm{H}\right)$-labelled luteinizing hormone releasing factor (LRF). Biochem. Biophys, Res. Commun., 50, $77 \mathrm{I}-778$.

Groom G. V., BoYns A. R., I973. Effect of hypothalamic releasing factors and steroids on release of gonadotrophins by organ cultures of human fotal pituitaries. J. Endocrin,, 59, 5I I-522.

Jutisz M., de la Llosa M. P., I969. L'adénosine-3', 5'-monophosphate cyclique, un intermédiaire probable de l'action de l'hormone hypothalamique FRF. C. R. Acad. Sc. (Paris) Sér. D, 268, I636-r639.

Jutisz M., de la Llosa M. P., I97o. Requirement of $\mathrm{Ca}^{++}$and $\mathrm{Mg}^{++}$ions for the in vitro release of follicle stimulating hormone from Rat pituitary glands and its subsequent biosynthesis. Endocrinology, 86, $76 \mathrm{x}-768$.

Jutisz M., Kraicer J., I975. Cellular Regulation of Adenohypophysial Function. Proc. Europ. Coll. Hypothalamic Hormones, Tübingen, Germany, February 26, x974, Verlag Chemie (in press).

Jutisz M., Kerdelhué B., Bérault A., I97o. Further studies on mechanism of action of luteinizing hormone releasing factor using in vivo and in vitro techniques. In The Human Testis, E. RoseMBERG and C. A. Paulsen (eds.), p. 221-228, Plenum Press, New York.

Jutisz M., Kerdelhuté B., Bérault A., de la Llosa M. P., I972. On the mechanism of action of the hypothalamic gonadotropin releasing factors. In Gonadotropins, B. B. SAXENA, C. G. Beling and H. M. GandY (eds.), p. 64-7I, Wiley and Sons, New York.

Jutisz M., Bérault A., Kerdelhué B., Thtoleyre M., 1975. Some aspects of the Cellular Mechanism of Action of Gonadotropin Releasing Hormone (s). In Some Aspects of Hypothalamic Regulation of Endocrine Functions, Symposia Medica " Hoechst ", Vienna, June 3rd-6th, I973, SchatTAuER Verlag, GMBH, Stuttgart (in press).

Kaneko T., Saito S., OKa H., Oda T., Yanaihara N., I972. Effects of synthetic releasing hormones on cyclic AMP levels and hormone release from antelior pituitary tissue. In Hypothalamic hypophysiotropic hormones : physiological and clinical studies, Excerpta Medica Amsterdam, 1973, C. GUAL and E. Rosemberg (eds.), Proceedings of the Serono Reseaich Foundation, U.S. A., Inc. Conference held at Acapulco, Mexico, June 29-July I, P. I98-203.

Kaneko T., Saito S., OKa H., Oda T., Yanaihara N., I973. Effects of synthetic LH-RH and its analogs on Rat anterior pituitary cyclic AMP and LH and FSH release. Metabolism, 22, 77-81.

Makino T., I973. Study on the intracellular mechanism of LH release in the anterior pituitary. Am. J. Obstet. Gynecol., 115, 606-614.

Marche P., Morgat J. L., Fromageot P., Kerdelhut B., Jutisz M., I972. ${ }^{8} H$-labelling of a synthetic decapeptide having $\mathbf{L H}$ and FSH releasing activity (LH-RH/FSH-RH). FEBS Letters, 26, 83-86.

Nakane P. K., 1970. Classification of anterior pituitary cell types with immuno-enzyme histochemistry. J. Histochem. Cytochem., 18, 9-20.

Naor Z., Koch Y., Chobsieng P., Zor U., I975. Personal communication.

RATNER A., I970. Stimulation of luteinizing hormone release in vitro by dibutyryl-cyclic-AMP and theophylline. Life Sci, 9, Part I I221-1226.

Robison G. A., Butcher R. W., Sutherland E. W., ig7r. in Cyclic $A M P$, Academic Press, New York and London, p. 36.

Spona J., I973 a. LH-RH interaction with the pituitary plasma membrane. FEBS Letters, 34, 24-27.

SPONA J., I973 $b$. LH-RH stimulated gonadotropin release mediated by two distinct pituitary receptors. FEBS Letters, 85, 59-63.

SPONA J., 1974. LH-RH-receptor interaction is inhibited by Des-His-2-Des-Gly-Io-LH-RH-ethylamide. FEBS Letters, 48, 88-92.

Sutherland E. W., OYe I., Butcher R. W., r965. The action of Epinephrine and the role of adenyl cyclase system in hormone action. Recent Progr. Horm. Res., 21, 623-646.

Zor U., Lamprecht S. A., Kaneko T., Schneider H. P. G., McCann S. M., Field J. B., TSAFRIRI A., LINDNER H. R., r972. Functional relations between cyclic-AMP, prostaglandins and luteinizing-hormone in rat pituitary and ovary. In Advances in Cyclic Nucleotide Research, Vol. I, Raven Press, New York, p. 503-520. 